Scot. med. J., 1973, 18: 3

\title{
CHANGES IN LEUCOCYTE ASCORBIC ACID DURING THE COMMON COLD
}

\author{
R. Hume and Elspeth Weyers \\ Department of Medicine, Southern General Hospital, Glasgow
}

\begin{abstract}
Summary. Leucocyte ascorbic acid was measured in 7 subjects during the common cold. There was a significant fall in L.A.A. to scorbutic levels within 24 hours of the onset of symptoms. By the fifth day the L.A.A. had returned to normal, which coincided with the cessation of symptoms. Absorption studies suggested 1 g. ascorbic acid per day as a prophylactic dose and $6 \mathrm{~g}$. ascorbic acid per day as a therapeutic dose. The effect of such supplements of ascorbic acid in 4 episodes of the common cold in 3 subjects suggests that the L.A.A. pattern can be changed by this therapy. The implications are discussed.
\end{abstract}

SINCE the publication of the monograph $\mathcal{N}_{\text {Vitamin } C \text { and the Common Cold, by Linus }}$ Pauling (1970), there has been much discussion in the public press and elsewhere both in America and in this country on the prophylactic and therapeutic value of ascorbic acid in infections by the common cold virus.

During the winter of 1971, we were able to observe the changes occurring in the leucocyte ascorbic acid levels (L.A.A.) in 7 individual members of the staff of one medical unit in a general hospital, during an outbreak of the common cold. Ascorbic acid saturation tests were also carried out to determine whether there was an optimum dose of ascorbic acid which would saturate both the white blood cells and the serum. The effect of 'optimum' doses of ascorbic acid during further episodes of the common cold was studied in 3 individuals. In view of the difficulty in carrying out detailed studies on individuals who are harbouring the common cold virus and who are taking supplements of ascorbic acid, we felt that these observations also were worth reporting.

\section{MATERIAL AND METHODS \\ Subjects \\ Seven members ( 2 males and 5 females) of the medical and nursing staff were studied while suffering from the common cold. By chance, 4 individuals had measurements of their L.A.A. performed during the week prior to the onset of symptoms. Six individuals had measurements performed on the first day of symptoms; 5 on the second day of symptoms; 7 on the third day of symptoms; 5 on the fourth day of symptoms; 3 on the fifth day of symptoms and 7 on the tenth day of symptoms. Symptoms had usually subsided by the fifth day.}

\section{Ascorbic acid saturation studies}

Following the 'colds', the 7 subjects agreed to take ascorbic acid daily, increasing the amount at weekly intervals. During the first week $0.2 \mathrm{~g}$. of ascorbic acid was taken daily, during the second week $1.0 \mathrm{~g}$. of ascorbic acid was taken daily, during the third week $3.0 \mathrm{~g}$. of ascorbic acid daily and during the fourth week $6.0 \mathrm{~g}$. of ascorbic acid daily. Four individuals volunteered to take $10.0 \mathrm{~g}$. of ascorbic acid daily, during the fifth week. The L.A.A. and the serum ascorbic acid (S.A.A.) were measured on 2 occasions each week in each individual and the mean of the 2 readings was used as the saturation level on that particular dose of ascorbic acid.

There were, therefore, 14 readings on the 7 subjects each week and 8 readings on the 4 subjects on the fifth week of observation. Most subjects experienced abdominal colic and some looseness of the bowels on first taking $3.0 \mathrm{~g}$. of ascorbic acid per day. However, this did not persist and there were no other side effects. The ascorbic acid was administered in divided doses in the form of effervescent ascorbic acid (Roche).

\section{Leucocyte ascorbic acid}

(L.A.A.) was measured by the method of Bessey

(1947) as modified by Denson and Bowers (1961)

which gives a mean normal value (24 observations) of $21.4 \mu \mathrm{g}$. per $10^{8}$ W.B.C. (range 16-36 $\mu \mathrm{g} . / 10^{8}$ W.B.C.).

\section{Serum ascorbic acid}

(S.A.A.) was measured by the method of Denson and Bowers (1961) and expressed as mg. per $100 \mathrm{ml}$. which gives a mean normal value (17 observations) of $1.05 \mathrm{mg}$. per $100 \mathrm{ml}$. (range $0.35-1.85 \mathrm{mg} . / 100 \mathrm{ml}$.).

\section{RESULTS}

Leucocyte ascorbic acid (L.A.A.) changes during the common cold (Table I, Fig. 1) The mean L.A.A. level of 4 subjects prior to the onset of symptoms was $20.0 \mu g$. per $10^{8}$ W.B.C. (S.D. \pm 3.3 ) which is in the normal range. On the first day of symptoms the mean L.A.A. level of 6 subjects was $10.3 \mu \mathrm{g}$ per $10^{8}$ W.B.C. (S.D. \pm 0.3 ) which is in the scorbutic range. On day 2 of symptoms the mean L.A.A. level for the 5 subjects had changed little, being $10.1 \mu \mathrm{g}$. per $10^{8} \mathrm{~W}$.B.C. (S.D. \pm 3.5$)$. On day 3 of symptoms the mean L.A.A, level for 7 subjects was $14.6 \mu \mathrm{g}$. 
per $10^{8}$ W.B.C (S.D. \pm 1.8 ), only 2 of the subjects being in the normal range. On day 4 of symptoms the mean L.A.A. for 5 subjects was $19.0 \mu \mathrm{g}$. per $10^{8}$ W.B.C. (S.D. \pm 2.4 ), all but one being in the normal range. On day 5 the mean L.A.A. of 3 subjects was $23.6 \mu \mathrm{g}$. per $10^{8}$ W.B.C. (S.D. \pm 7.7 ) one reading being below normal. Ten days after the onset of symptoms the mean L.A.A. for the 7 subjects was $24.0 \mu \mathrm{g}$. per $10^{8}$ W.B.C. (S.D. \pm 6.5 ) and all the readings were in the normal range.

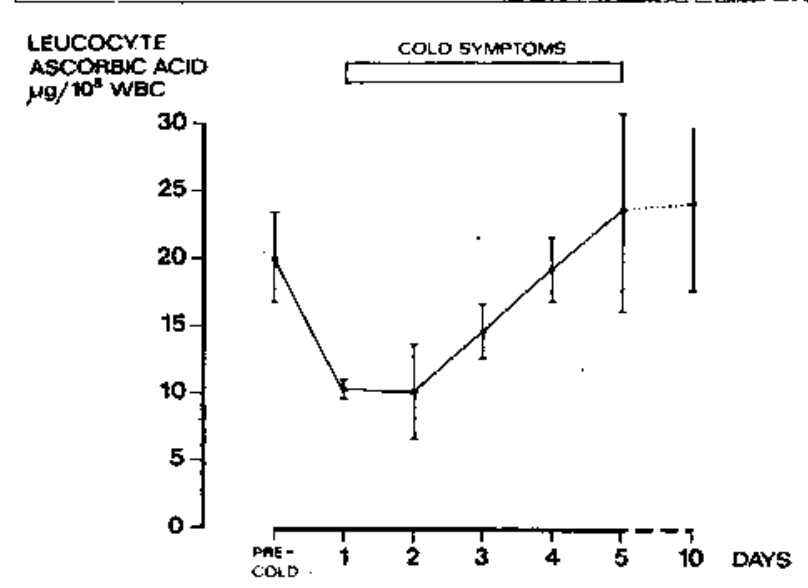

Fig. 1. Fall in leucocyte ascorbic acid during the common cold. Means and one standard deviation.

\section{Ascorbic acid saturation studies}

\section{(Table II, Fig. 2)}

L.A.A. levels. The mean L.A.A. level of the 7 subjects ( 7 observations) prior to the ingestion of ascorbic acid was $18.9 \mu \mathrm{g}$. per $10^{8}$ W.B.C. (S.D. \pm 5.8). The mean L.A.A. level of the 7 subjects (14 observations) on 0.2 g. of ascorbic acid per day was $20.7 \mu \mathrm{g}$. per $10^{8}$ W.B.C. (S.D. \pm 6.2 ) which is not significantly different from the pre-ascorbic acid level $(\mathrm{i}=1.0843 \mathrm{P}>0.05)$.

The mean L.A.A. of the 7 subjects (14 observations) on $1.0 \mathrm{~g}$. of ascorbic acid per day was $28.8 \mu$ g. per $10^{8}$ W.B.C. (S.D. \pm 6.9 ) which is a significant increase from the unsupplemented level $(\mathrm{t}-=3.5063 ; \mathrm{P}<0.005)$ and from the $0.2 \mathrm{~g}$. per day level $(\mathrm{t}=3.2806$; $\mathrm{P}<0.005)$. The mean L.A.A. of the 7 subjects (14 observations) on $3.0 \mathrm{~g}$. of ascorbic acid per day was $25.0 \mu \mathrm{g}$. per $10^{8}$ W.B.C. (S.D. \pm 5.9$)$ which is a significant increase from the pre-ascorbic acid level $(\mathrm{t}-2.2917$; $\mathrm{P}<0.05)$ but not significantly different from the 1,0 g. per day level $(\mathrm{t}=1.5851 ; \mathrm{P}>0.05)$. The mean L.A.A. of the seven subjects (14 observations) on $6.0 \mathrm{~g}$. of ascorbic acid per day was $29.4 \mu$ g. per $10^{8}$ W.B.C. (S.D. \pm 6.1 ) which is significantly different from the preascorbic level $(\mathrm{t}=3.8780 ; \mathrm{P}<0.005)$ but not significantly different from the $1.0 \mathrm{~g}$. per day level $(\mathrm{t}=0.1600 ; \mathrm{P}<0.05)$ or the $3.0 \mathrm{~g}$. per day level $(\mathrm{t}=1.9370 ; \mathrm{P}>0.05)$. The mean L.A.A. of the 4 subjects ( 8 observations) on $10.0 \mathrm{~g}$. of ascorbic acid per day was $30.2 \mu \mathrm{g}$. per $10^{8}$ W.B.C. (S.D. \pm 12.3 ) was significantly different from the unsupplemented level $(\mathrm{t}=2.3171 ; \mathrm{P}>0.05)$, but was not significantly different from the $1.0 \mathrm{~g}$. per day level $(\mathrm{t}=0.2832 ; \mathrm{P}>0.05$ or the 3.0 g. per day level $(\mathrm{t}=1.1140 ; \mathrm{P}>0.05)$ or the $6.0 \mathrm{~g}$. per day level $(\mathrm{t}=0.1686 ; \mathrm{P}>0.05)$.

The mean S.A.A. level of the 7 subjects (7 observations) prior to the ingestion of ascorbic acid was $0.81 \mathrm{mg}$. per $100 \mathrm{ml}$. (S.D. \pm 0.52$)$. The mean S.A.A. of the 7 subjects (14 observations) on $0.2 \mathrm{~g}$. ascorbic acid per day was $1.29 \mathrm{mg}$. per $100 \mathrm{ml}$. (S.D. \pm 0.39 ) which is just significantly different from the unsupplemented level $(\mathrm{t}=2.1828 ; \mathrm{P}<0.05)$. The mean S.A.A. level of the 7 subjects (14 observations) on $1.0 \mathrm{~g}$. of ascorbic acid per day was $1.68 \mathrm{mg}$. per $100 \mathrm{ml}$. (S.D. \pm 0.39 ) which is significantly different from the unsupplemented level $(t=3.9313 ; \quad P<0.001)$ and significantly different from the $0.2 \mathrm{~g}$. per day level $(\mathrm{t}=2.6635 ; \mathrm{P}<0.02)$. The mean S.A.A. level of the 7 subjects (14 observations) on $3.0 \mathrm{~g}$. ascorbic acid per day was $1.69 \mathrm{mg}$. per $100 \mathrm{ml}$. (S.D. \pm 0.28 ) which is significantly different from the unsupplemented level $(\mathrm{t}=4.2348$; $\mathrm{P}<0.001)$ but not significantly different from the 1.0 g. per day level $(\mathrm{t}=0.1348 ; \mathrm{P}>0.05)$. The mean S.A.A. level of the 7 subjects (14 observations) on $6.0 \mathrm{~g}$. of ascorbic acid per day was $2.36 \mathrm{mg}$. per $100 \mathrm{ml}$. (S.D. \pm 0.44 ) which is significantly different from the $3.0 \mathrm{~g}$. per day level $(\mathrm{t}=4.7704 ; \mathrm{P}<0.001)$, the $1.0 \mathrm{~g}$. per day level $(\mathrm{t}=6.5561 ; \mathrm{P}<0.001)$ and the unsupplemented level $(\mathrm{t}=6.7923 ; \mathrm{P}<0.001)$. The mean S.A.A. level of the 4 subjects ( 8 observations) on $10.0 \mathrm{~g}$. ascorbic acid per day was $2.40 \mathrm{mg}$. per $100 \mathrm{ml}$. (S.D. \pm 0.27 ) which is not significantly different from the $6.0 \mathrm{~g}$. per day level $(\mathrm{t}=0.0106 ; \mathrm{P}>0.05)$ but was significantly different from the $3.0 \mathrm{~g}$. per day level $(\mathrm{t}=5.7517 ; \mathrm{P}<0.001)$, the $1.0 \mathrm{~g}$. per day 
Table I. Changes in leucocyte ascorbic acid during the common cold.

\begin{tabular}{|c|c|c|c|c|c|c|c|c|c|}
\hline Day & $\begin{array}{c}\text { Subject } \\
1\end{array}$ & $\begin{array}{c}\text { Subject } \\
2\end{array}$ & $\underset{3}{\text { Subject }}$ & $\begin{array}{c}\text { Leucocyte } \\
\text { Subject } \\
4\end{array}$ & $\begin{array}{l}\text { ascorbic } \\
\text { Subject } \\
5\end{array}$ & $\begin{array}{c}\text { acid } / 10^{8} \\
\text { Subject } \\
6\end{array}$ & $\begin{array}{l}\text { W.B.C. } \\
\text { Subject } \\
7\end{array}$ & Mean & $\begin{array}{l}\text { Standard } \\
\text { deviation }\end{array}$ \\
\hline Pre-cold & 24.5 & 18.6 & - & 16.8 & 一 & 20.0 & 一 & 20.0 & 3.3 \\
\hline 1 & 10.5 & 9.7 & 10.3 & - & 10.1 & 10.4 & 10.8 & 10.3 & 0.3 \\
\hline 2 & 8.4 & 8.1 & 11.9 & 15.3 & 6.8 & $\longrightarrow$ & $\rightarrow$ & 10.1 & 3.5 \\
\hline 3 & 14.6 & 11.7 & 14.4 & 16.3 & 13.4 & 14.8 & 17.1 & 14.6 & 1.8 \\
\hline 4 & 21.5 & 15.9 & - & 17.1 & - & 19.7 & 20.9 & 19.0 & 2.4 \\
\hline 5 & 28.1 & - & - & - & - & 14.7 & 28.0 & 23.6 & 7.7 \\
\hline 10 & 26.6 & 22.1 & 20.2 & 17.1 & 23.8 & 21.3 & 37.2 & 24.0 & 6.5 \\
\hline
\end{tabular}

Table II Changes in leucocyte and serum ascorbic acid following increasing supplements of ascorbic acid.

\begin{tabular}{cccccc}
\hline $\begin{array}{c}\text { Supplements } \\
\text { of ascorbic acid } \\
\text { (g./day) }\end{array}$ & $\begin{array}{c}\text { Number } \\
\text { of } \\
\text { observations }\end{array}$ & $\begin{array}{c}\text { Mean leucocyte } \\
\text { Ascorbic acid level } \\
\left(\mu \mathrm{g} / 10^{8} \text { W.B.C.) }\right.\end{array}$ & $\begin{array}{c}\text { Standard } \\
\text { deviation }\end{array}$ & $\begin{array}{c}\text { Mean serum } \\
\text { Ascorbic acid level } \\
\text { (mg./100 ml.) }\end{array}$ & $\begin{array}{c}\text { Standard } \\
\text { deviation }\end{array}$ \\
\hline Unsupplemented & 7 & 18.9 & 5.8 & 0.81 & 0.52 \\
0.2 & 14 & 20.7 & 6.2 & 1.29 & 0.39 \\
1.0 & 14 & 28.8 & 6.9 & 1.68 & 0.39 \\
3.0 & 14 & 25.0 & 5.9 & 1.69 & 0.28 \\
6.0 & 14 & 29.4 & 6.1 & 2.36 & 0.44 \\
10.0 & 8 & 30.2 & 12.3 & 2.40 & 0.27 \\
\hline
\end{tabular}

Table III. Changes in leucocyte ascorbic acid during the common cold while ingesting supplements of ascorbic acid

\begin{tabular}{|c|c|c|c|c|c|c|c|}
\hline $\begin{array}{l}\text { Ascorbic acid } \\
\text { supplement } \\
\text { (g./day) }\end{array}$ & Day & $\underset{1}{\text { Subject }}$ & $\underset{2}{\text { Subject }}$ & $\begin{array}{c}\text { cyte asco } \\
\text { Subject } \\
2^{*}\end{array}$ & $\begin{array}{l}\text { acid } / 10^{8} \\
\text { Subject } \\
3\end{array}$ & Mean & $\begin{array}{l}\text { Standard } \\
\text { deviation }\end{array}$ \\
\hline $\begin{array}{l}1 \\
6 \\
6 \\
6 \\
1 \\
1\end{array}$ & $\begin{array}{c}\text { Pre-cold } \\
1 \\
2 \\
3 \\
4 \\
5\end{array}$ & $\begin{array}{l}33.4 \\
24.0 \\
22.6 \\
18.1 \\
28.0 \\
33.5\end{array}$ & $\begin{array}{l}29.7 \\
29.6 \\
29.4 \\
20.5 \\
32.8 \\
31.8\end{array}$ & $\begin{array}{l}29.7 \\
29.7 \\
22.1 \\
28.2 \\
31.2 \\
29.7\end{array}$ & $\begin{array}{l}29.0 \\
20.2 \\
32.0 \\
28.7 \\
26.2 \\
31.8\end{array}$ & $\begin{array}{l}30.5 \\
25.9 \\
26.5 \\
23.9 \\
29.5 \\
31.7\end{array}$ & $\begin{array}{l}2.0 \\
4.6 \\
4.9 \\
5.4 \\
3.0 \\
1.6\end{array}$ \\
\hline
\end{tabular}

* Second cold episode

level $(\mathrm{t}=5.0768 ; \mathrm{P}<0.001)$ and the unsupplemented level $(\mathrm{t}=7.2737$; $\mathrm{P}<0.001)$.

The effect of ascorbic acid ingestion on the L.A.A. changes during the common cold. The effect of $0.2 \mathrm{~g}$. of ascorbic acid per day (Fig. 4). One of the subjects developed a 'cold' while consuming $0.2 \mathrm{~g}$. of ascorbic acid per day. The changes in L.A.A. were similar to that of the subjects not ingesting ascorbic acid. The pre-cold L.A.A. was $24.5 \mu \mathrm{g}$. per $10^{8}$ W.B.C. and on the first day of symptoms the L.A.A. fell to $10.5 \mu \mathrm{g}$. per $10^{8}$ W.B.C, on the second day the L.A.A. was 8.4 $\mu$ g. per $10^{8}$ W.B.C., on the third day the L.A.A. was $14.6 \mu \mathrm{g}$. per $10^{8}$ W.B.C., on the fourth day the L.A.A. was $21.5 \mu \mathrm{g}$. per $10^{8}$ W.B.C. and on the fifth day the L.A.A. was $28.1 \mu \mathrm{g}$. per $10^{8}$ W.B.C. which coincided with the disappearance of symptoms. On the tenth day the L.A.A. was $26.6 \mu \mathrm{g}$. per $10^{8}$ W.B.C.

The effect of $1.0 \mathrm{~g}$, of ascorbic acid per day as a prophylactic dose and 6.0 g. per day during the common cold (Table III Fig. 3).

Three of the subjects developed 4 episodes of common cold symptoms while taking $1.0 \mathrm{~g}$. of ascorbic acid per day. The dose of ascorbic acid was immediately increased to $6.0 \mathrm{~g}$. per day for 3 days and thereafter $1.0 \mathrm{~g}$. per day. It was noted that the lowest mean L.A.A. level occurred on the third day namely $23.9 \mu \mathrm{g}$. per $10^{8}$ W.B.C. and none of the individual readings fell below the normal level during the 5 days of observation. By the fifth day the levels had returned to the pre-cold level.

\section{DISCUSSION}

Following infection with the common cold virus, the L.A.A. level falls within 24 hours to very low levels $\left(10.3 \mu \mathrm{g} . / 10^{9}\right.$ W.B.C. \pm 0.3$)$ which are well below the normal range (16-36 $\mu \mathrm{g} . / 10^{8}$ W.B.C.) and thereafter gradually return to normal by the fifth day (23.6 $\mu \mathrm{g} . / 10^{8}$ W.B.C. \pm 7.7 ) which coincides 


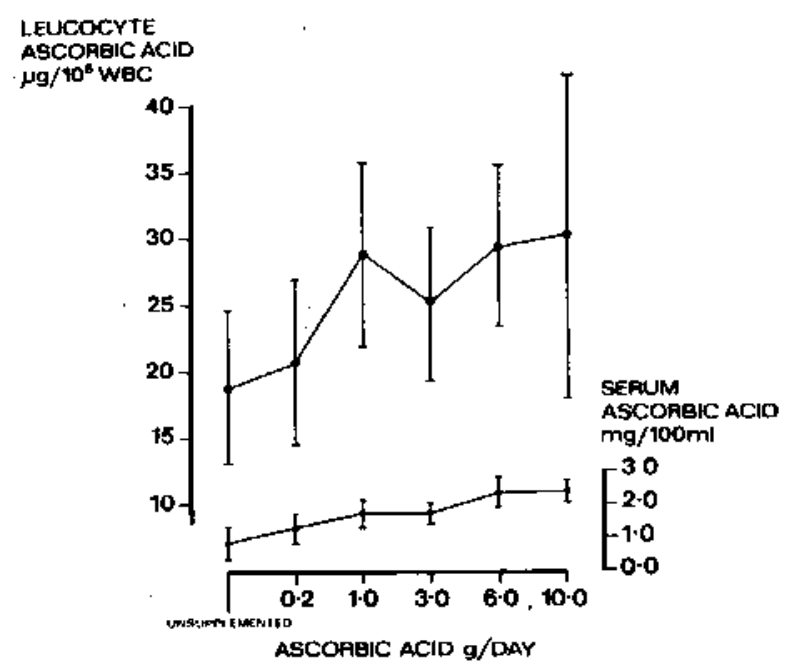

Fig. 2. Changes in leucocyte ascorbic acid and serum following increasing supplements of ascorbic acid. Means and one standard deviation.

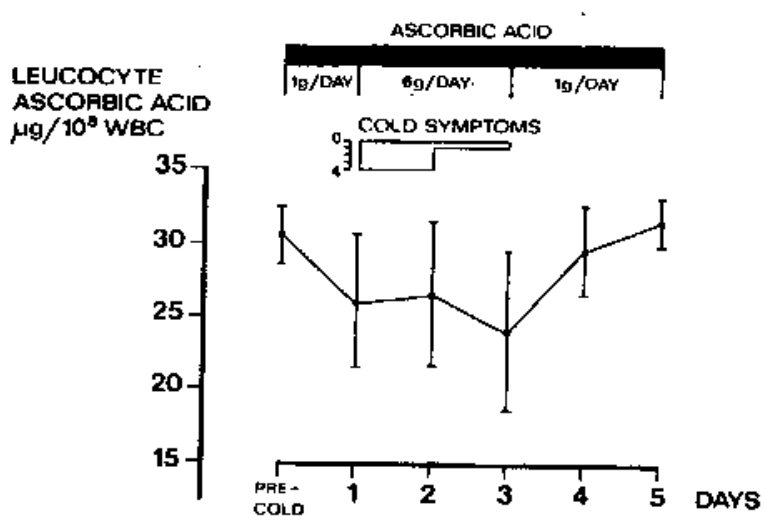

Fig. 3. Changes in leucocyte ascorbic acid during the common cold while ingesting supplements of ascorbic acid. Means and one standard deviation.

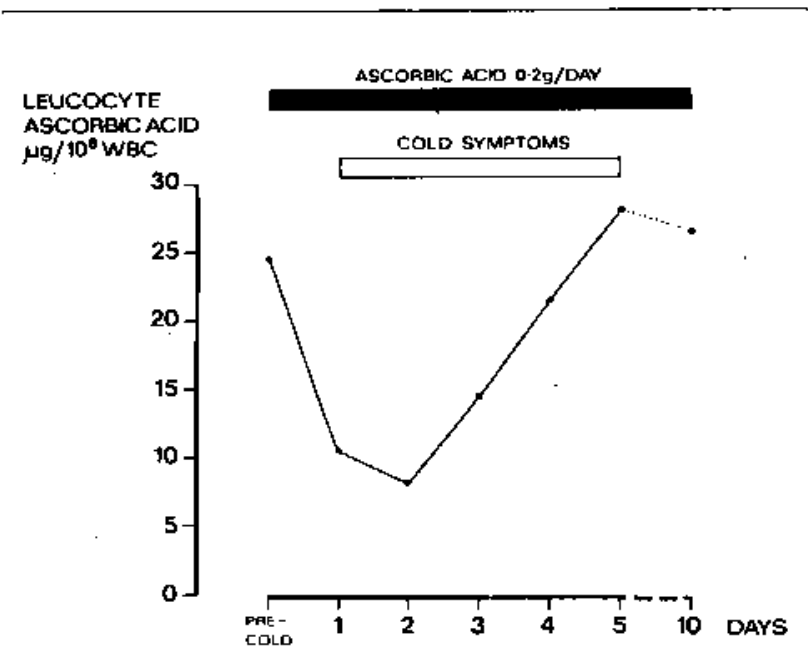

Fig. 4. Changes in leucocyte ascorbic acid during the common cold while ingesting $0.2 \mathrm{~g}$. of ascorbic acid per day. One subject. with the cessation of symptoms. We have observed similar changes in L.A.A. following acute myocardiar infarction although in that instance the L.A.A. took approximately 14 days to return to normal (Hume et al., 1972). It would appear, therefore, that both major and minor 'stresses' can have a profound effect on L.A.A. rendering interpretation of an isolated L.A.A. difficult unless account is taken of the circumstances under which the test is carried out.

Having observed these changes in L.A.A. following an episode of the common cold, and in view of the controversy regarding the effect of ascorbic acid both as a prophylactic and a therapeutic agent, we wondered whether supplements of ascorbic acid could alter this pattern. The first observation that supplements of $0.2 \mathrm{~g}$. ascorbic acid per day did not alter the pattern of L.A.A. during the common cold (Fig. 4) prompted saturation studies in normal individuals to determine the amount of ascorbic acid per day required to saturate the leucocytes and the serum. Within the limitations of the studies carried out, it was not possible to show a significant rise in L.A.A. on increasing the ingested amount of ascorbic acid from $1.0 \mathrm{~g}$. per day to $10.0 \mathrm{~g}$. per day either by comparison of the means or analysis of variance (Fig. 2). Interestingly, the fall in L.A.A. (which did not reach statistical levels), on starting $3.0 \mathrm{~g}$. of ascorbic acid per day was, in nearly all subjects, associated with abdominal colic and looseness of the bowels suggesting the fall was due to malabsorption of the ascorbic acid. However, bowel symptoms did not persist and there were no other side effects. With regard to the serum, it was not possible to show an increase in ascorbic acid concentration on increasing the ingestion of ascorbic acid from 6.0 g. per day to 10.0 g. per day either by comparison of the means or analysis of variance (Fig. 2). While aware of the statistical hazards implicit in analysis of such small numbers of observations and the limited range of ascorbic acid doses used, nevertheless, it was decided on the evidence to use $1.0 \mathrm{~g}$. per day as a prophylactic and $6.0 \mathrm{~g}$. per day as a therapeutic dose. The 4 'colds' experienced by 3 of the individuals who volunteered to take $1.0 \mathrm{~g}$. per day 
throughout the winter months and $6.0 \mathrm{~g}$. for 3 days at the first appearance of cold symptoms are shown in Figure 3. It can be seen that the peak fall in L.A.A. has occurred on day 3 of symptoms instead of day one as in the unsupplemented group and that the lowest recorded L.A.A. in each case is still within the normal range. Pre-cold levels of L.A.A. are reached again in the fourth or fifth day. The cold symptoms persisted for 2 to 3 days.

While the number of subjects involved in these observations is small, nevertheless, the pattern of change of L.A.A. during the common cold is so consistent in each individual and the effect of ascorbic acid feeding so clear cut, we feel the small numbers do not detract from the results. With regard to the saturation studies, it has been claimed that L.A.A. saturation may be obtained by smaller amounts of ascorbic acid administered over a longer period of time (Goldsmith, 1961; Brocklehurst et al., 1968; Andrews, et al 1969; Wilson \& Loh, 1969; Booth \& Todd, 1970; Loh \& Wilson, 1971a; Loh \& Wilson, 19716). The value of more prolonged courses of smaller amounts of ascorbic acid and more acute courses of larger amounts of ascorbic acid as a prophylactic or therapeutic agent in the common cold have produced only discrepant reports. (Cowan et al., 1942; Bartley et al, 1953; Ritzd, 1961; Glazebrook \& Thomson, 1962; Walker et al, 1967; Regnier, 1969; Wilson \& Loh, 1969; Wilson, 1971). We feel a further trial would be justified along the lines suggested here, namely, $1.0 \mathrm{~g}$. ascorbic acid per day as a prophylactic and $6.0 \mathrm{~g}$. or $10.0 \mathrm{~g}$. per day as a therapeutic measure after challenge by the common cold virus. Those suggestions are not incompatible with the recommendations of Linus Pauling (1970) who suggests 1 to $2 \mathrm{~g}$. per day for good health and 4 to $10 \mathrm{~g}$. per day to combat the common cold.

ACKNOWLEDGEMENTS. We are grateful to the members of the medical and nursing staff who volunteered to take part in the studies. We are especially grateful to Sister T. White who presented us with our first cold.

\section{REFERENCES}

Andrews, J., Letcher, M., Brook, M. (1969). Vitamin $\mathrm{C}$ supplementation in the elderly: a 17 month trial in an old persons home. British Medical Journal, 2, 416
Bartley, W., Krebs, H. A., O'Brien, J. R. P. (1953). Vitamin $C$ requirements of human adults. Special Report Series. Medical Research Council (London). No. 280

Bessey, O. A., Lowry, O. H., Brock, M. J. (1947). The quantitative determination of ascorbic acid in small amounts of white blood cells and platelets. Journal of Biological Chemistry, 168, 197

Booth, J. B., Todd, G. B. (1970). Subclinical scurvyhypovitaminosis C. British Journal of Hospital Medicine, 4, 513

Brocklehurst, J. C., Griffiths, L. L., Taylor, G. F. The clinical features of chronic vitamin deficiency. A therapeutic trial in geriatric hospital patients. Gerontologia Clinica, 10, 309

Cowan, D. W., Diehl, H. S., Baker, A. B. (1942). Vitamins for the prevention of colds. Journal of the American Medical Association, 120, 1268

Denson, K. W., Bowers, E. F. (1961). The determination of ascorbic acid in white blood cells. Clinical Science, 21, 157

Gazebrook, A. J., Thomson, S. (1942). The administration of Vitamin $\mathrm{C}$ in a large institute and its effect on general health and resistance to infection. Journal of Hygiene (London), 42, 1

Goldsmith, G. A. (1961). Human requirements for vitamin C and its use in clinical medicine. Annals of New York Academy of Sciences, 92, 230

Hume, R., Weyers, E., Rowan, T., Reid, D. A., Hillis, W.S. (1972). Leucocyte ascorbic acid levels after acute myocardial infarction. British Heart Journal, 24, 238

Loh, H. S., Wilson, C. W. M. (1971a). Relationship between leucocyte and plasma ascorbic acid concentrations. British Medical Journal, 3, 733

Loh, H. S., Wilson, C. W. M. (1971b). Relationship between leucocyte ascorbic acid and haemoglobin levels at different ages. International Journal of Vitamin and Nutrition Research, 41, 259

Pauling, L. (1970). Vitamin C and the common cold. San Francisco: W. H. Freeman \& Company.

Regnier, E. (1968). The administration of large doses of ascorbic acid in the prevention and treatment of common cold. Review of Allergy, 22, 834 and 948

Ritzel, G. (1961). Critical evaluation of vitamin C as a prophylactic and therapeutic agent in colds. Helvetica Medica Acta, 28, 63

Tyrrell, D. A. J. (1965). Common colds and related diseases. London: Edward Arnold Limited

Walker, G. H., Bynoe, M. L., Tyrrell, D. A. J. (1967). Trial of ascorbic acid in prevention of colds. British Medical Journal, 2, 603

Wilson, C. W. M. (1971). Vitamin C and the common cold. British Medical Journal, 1, 669

Wilson, C. W. M., Loh, H. S. (1969). Ascorbic acid and upper respiratory inflammation. Acta Allergolica, 24, 367 